\title{
Me, Microscopy and No PhD
}

\section{Roger Kerstin}

\section{EDAX/Gatan, Suwanee, Georgia, United States}

Starting my career in the technology field wasn't really part of my plan. After graduating from College with a bachelor's degree, I tried to go into selling life insurance. After one year, I decided it wasn't for me and just quit. I then realized I didn't have a job. I decided to go to a temp agency and try my hand at various jobs, knowing that these were just jobs and not a real career for me. In my $3^{\text {rd }}$ temp job as a baker, I was working from 10pm to 6am baking for Panera. This way I could still interview for a career job if something came along. Well, one month from the day I started at Panera, I had an interview lined up with a small tech company to become their purchasing agent. I thought, what a great job to be able to shop and buy lots of items and not spend any of my own money. Well, purchasing was fun, I loved doing it, but there was something missing. I saw everyday some of the salespeople and the technical applications team looking at new samples, new challenges, and new opportunities with their customers and I thought that was pretty cool.

After spending many years in purchasing I started to branch out. Since it was a small company at the time, I wore several different hats for them and over 15 years I held 12 different positions. Some of those positions included inventory control, purchasing, marketing, design, facilities manager and then sales. I said that I would never do sales again after selling life insurance, but someone told me selling a product is different than selling insurance, so I gave it a try. I jumped in headfirst and really wanted to get it right. I worked with the applications team, so I understood the technical aspect of the equipment and customers' needs. I challenged myself to be able to demo the equipment and discuss customers applications without the need of an applications team member.

Ever since then, I have been working with many different analytical techniques that just keep broadening my scope of knowledge. I never thought I would someday be interacting, on a daily basis, with all these PhD's and highly educated people. Jumping into this field's technology early on was such a big advantage, and I don't think I would be where I am today if it wasn't for that.

I love working in the Microscopy field. I love seeing firsthand the advances and breakthroughs that the equipment I sell makes. I never thought I would be where I am today when I was in school. I feel very blessed to be where I am, even without a PhD.

The ability to SEE the "unseen" world is inspirational (1).

References:

1. Madiowink, M. (2014) Stuff Matters: Exploring the Marvelous Materials That Shape Our Man-Made World Boston New York, Houghton Mifflin Harcourt 